\title{
Personality, death anxiety, and gender
}

\author{
JAMES A. THORSON and F. C. POWELL \\ University of Nebraska, Omaha, Nebraska
}

\begin{abstract}
Previous studies of personality and death anxiety have ignored the issue of gender. Presented are data for 426 adults, ranging in age from 18 to 90 years old, with correlates of personality traits and death anxiety scores. Men and women are shown to differ on 8 of 15 comparisons.
\end{abstract}

There are some indications in the literature that death anxiety and certain elements of personality are related. Thorson (1977) reported several significant correlations between a measure of death anxiety and a number of the traits assessed by the Edwards Personal Preference Schedule (Edwards, 1959). Lonetto and Templer (1986) report a negative correlation of Templer's Death Anxiety Scale (DAS; Templer, 1970) with the K scale of the Minnesota MultiPhasic Personality Inventory and positive, significant correlations of the DAS with several measures of anxiety. Neuroticism or emotionality have been found to be related to various measures of death anxiety (Frazier \& Foss-Goodman, 1988-89; Howells \& Field, 1982; Loo, 1984; Neufeldt \& Holmes, 1979; Templer, 1970, 1972). Davis, Miller, Johnson, McAuley, and Dinges (1992) found the DAS and the Revised UCLA Loneliness Scale to be positively related for women but not for men.

With the exception of the Davis et al. (1992) study, the issue of gender has usually been ignored in correlational studies of death anxiety and personality. However, men and women have been shown to construe fear of death differently (Lonetto \& Templer, 1986). Women, for example, seem to express higher fears of decomposition and the pain associated with dying (Diggory \& Rothman, 1961; Thorson \& Powell, 1990). Furthermore, it is not unusual for various personality measures to report separate norms for males and females. It would seem reasonable, then, to look for separate correlates of personality traits and death anxiety for men and women.

\section{METHOD}

As a part of another study (Thorson \& Powell, 1993), we gathered data from 136 men and 290 women who ranged in age from 18 to 90 years old; their mean age was 37.9 ( $S D=21.7$ years old $)$. Among other measures, they completed the Edwards Personal Preference Schedule (Edwards, 1959), an instrument that provides scores on 15 different personality traits, and the Revised Death Anxiety Scale (Thorson \& Powell, 1992), a 25-item questionnaire that gives an overall fear-ofdeath score.

Address correspondence to James A. Thorson, Department of Gerontology, University of Nebraska, Omaha, NE 68182.
Table 1

Correlations of Death Anxiety Scores with Edwards Personality Traits, by Gender

\begin{tabular}{lcc}
\multicolumn{1}{c}{ Trait } & $\begin{array}{c}\text { Males } \\
(n=136)\end{array}$ & $\begin{array}{c}\text { Females } \\
(n=290)\end{array}$ \\
\hline Achievement & .09 & .11 \\
Deference & -.16 & $-.32 \dagger$ \\
Order & .04 & $-.22 \dagger$ \\
Exhibition & .15 & $.14^{*}$ \\
Autonomy & .10 & -.06 \\
Affiliation & $-.18^{*}$ & -.11 \\
Intraception & .07 & -.02 \\
Succorance & -.05 & .09 \\
Dominance & -.00 & .05 \\
Abasement & -.06 & .06 \\
Nurturance & -.12 & -.03 \\
Change & -.10 & $-.12^{*}$ \\
Endurance & .06 & $-.14^{*}$ \\
Heterosexuality & .07 & $.23 \dagger$ \\
Aggression & .08 & $.27 \dagger$ \\
\hline
\end{tabular}

${ }^{*} p<.05 . \quad \dagger p<.01$.

\section{RESULTS AND DISCUSSION}

The women's mean score on the death anxiety scale was $45.7(S D=18.7)$ and the men's was $44.5(S D=14.8)$, a difference that was not significant. Table 1 presents Pearson correlations for men and for women of the Revised Death Anxiety Scale scores and the personality traits that make up the Edwards Personal Preference Schedule.

For males, the only significant correlation was for affiliation; men lower in that trait scored somewhat higher on death anxiety. There were several significant correlations among the data from women respondents: There were negative relationships found between death anxiety and deference, order, change, and endurance. Positive correlations were found between exhibition, heterosexuality, and aggression and the death anxiety score.

In conclusion, we have presented data from 426 adults indicating differences by gender in the relationship between death anxiety and personality. This presents a methodological issue that should be addressed in future studies of death anxiety and personality.

\section{REFERENCES}

Davis, S. F., Miller, K. M., Johnson, D., McAuley, K., \& 
DINGES, D. (1992). The relationship between optimism-pessimism, loneliness, and death anxiety. Bulletin of the Psychonomic Society, 30, 135-136.

Diggory, J. C., \& Rothman, D. (1961). Values destroyed by death. Journal of Abnormal \& Social Psychology, 63, 205-210.

Edwards, A. L. (1959). Edwards Personal Preference Schedule revised manual. New York: The Psychological Corporation.

Frazier, P. H., \& Foss-Goodman, D. (1988-89). Death anxiety and personality: Are they truly related? Omega, 19, 265-274.

Howells, K., \& FielD, D. (1982). Fear of death and dying among medical students. Social Science \& Medicine, 16, 1421-1424.

LonetTo, R., \& TeMPLER, D. I. (1986). Death anxiety. Washington, DC: Hemisphere.

Loo, R. (1984). Personality correlates of the Fear of Death and Dying scale. Journal of Clinical Psychology, 40, 120-122.

NeufeldT, D. E., \& Holmes, C. B. (1979). Relationship between personality traits and fear of death. Psychological Reports, 45, 907-910.
Templer, D. I. (1970). The construction and validation of a Death Anxiety Scale. Journal of General Psychology, 82, 165-177.

TEMPLER, D. I. (1972). Death anxiety: Extraversion, neuroticism, and cigarette smoking. Omega, 3, 53-56.

ThORSON, J. A. (1977). Variations in death anxiety related to college students' sex, major field of study, and certain personality traits. Psychological Reports, 40, 857-858.

Thorson, J. A., \& Powell, F. C. (1990). Elements of death anxiety and meanings of death. Journal of Clinical Psychology, 44, 691-701.

Thorson, J. A., \& Powell, F. C. (1992). A Revised Death Anxiety Scale. Death Studies, 16, 507-521.

ThORSON, J. A., \& PowELL, F. C. (1993). Relationships of death anxiety and sense of humor. Psychological Reports, 72, 1364-1366.

(Manuscript received June 28, 1993.) 